\title{
A comprehensive study on the quality of sustainability reporting disclosure between Indonesia and other countries
}

\author{
Komang Dandy Andriadi ${ }^{\mathrm{a}}$ and Desak Nyoman Sri Werastuti ${ }^{\mathrm{b}^{*}}$
}

${ }^{\mathrm{a}}$ Master of Accounting student Ganesha Education University, Indonesia

${ }^{b}$ Lecturer in Master of Accounting at Ganesha University of Education, Indonesia

\section{H R O N I C L E A B S T R A C T}

Article history:

Received March 10, 2021

Received in revised format May

102021

Accepted June 102021

Available online

June 112021

Keywords:

Sustainability report

Economic

Social

Environmental performance

\begin{abstract}
The shift in the business paradigm towards a more sustainable one has placed a balance between people, profit and the planet as a corporate culture. However, based on previous empirical studies, very few companies have put sustainability as the soul of their business, especially in the types of industries that are not obliged to report their social responsibility activities. This study aims to compare the quality of the sustainability report based on the GRI G4 indicator for foreign and domestic companies engaged in construction services. The data was taken using a purposive method on construction service companies that published their 2017 sustainability reports and found 30 companies. The quality of the report is compared between the three indicators, namely economic, social and environmental. The results showed that in terms of quality of disclosure, there was no difference between domestic and foreign construction service companies, whether tested per category or tested collectively. The results of this study reinforce the previous finding that companies are still very dependent on the regulatory compliance approach only in implementing sustainability, especially in the construction service industry.
\end{abstract}

\section{Introduction}

Disclosure of information by a company is the main basis for investors to support safe and profitable investment decisions. The information needed by investors is not only financial information but also non-financial information. A shift in the business paradigm where non-financial information needs to be disclosed has influenced companies to present this information in a more comprehensive form. Additional reports can be in the form of analysis, recommendations, social and environmental accountability, and feasibility reports (Atmadja \& Saputra, 2018; Mdee \& Thorley, 2016; Saputra et al., 2019). This is indeed a demand for companies today since the company's paradigm has shifted to following the triple bottom line trend. In the triple bottom line, one of the pillars is about preserving the environment (planet) (Malizia \& MonmanyGarzia, 2019). The pillar of environmental preservation is becoming increasingly popular and companies are trying to fulfill it in an effort towards mandatory reporting for sustainability (Istianingsih et al., 2020; Thornton, 2013). This mandatory sustainability reporting is fully supported by the government's efforts to reduce environmental problems with the issuance of Law No.40 of 2007 concerning Limited Liability Companies. Article 74 (1) states "Companies that carry out business activities related to natural resources are obliged to carry out social and environmental responsibility". Following up on the law, the government issued Government Regulation No.47 of 2012 on Social and Environmental Responsibility of Limited Liability Companies (Cho \& Patten, 2013; Nagy et al., 2014). This government regulation can mean that companies are not

* Corresponding author.

E-mail address: dsriwerastuti@gmail.com (D. N. S. Werastuti) 
only required to carry out their social and environmental responsibilities, but also must report these accountability activities (Karmawan, 2017). The preparation of a sustainability report is a form of responsibility and compliance with the overall disclosure principle of company activities, both from financial and non-financial aspects. The principles in the sustainability report are listed in the Global Reporting Initiatives (GRI), namely transparency, accountability, responsibility, independency, and fairness (Istianingsih et al., 2020). At the international level, guidelines for preparing sustainability reports are directed to follow the Global Reporting Initiative (GRI) standards and are prepared separately from financial reports or annual reports (Buslepp et al., 2019; Istianingsih et al., 2020).

GRI defines sustainability reporting as the practice of measuring, disclosing, and being accountable to internal and external stakeholders regarding the organization's performance in achieving sustainable development goals (Lombardi et al., 2019; $\mathrm{Ng}, 2018$ ). Although the quality of sustainability reporting in Indonesia continues to grow, the number of companies in Indonesia reporting sustainability reports is still far behind compared to developed countries, even though it is among the best in Southeast Asia. The factor that makes companies reluctant to make a sustainability report is that the company is not transparent in running its business. The second factor is that the company considers the sustainability report as an additional cost. Whereas the third, namely, there is no regulation that requires a company to release a sustainability report or it can be called voluntary (Kim \& Todorovic, 2013; Thornton, 2013). Efforts to encourage the publication and use of sustainability reports by companies in Indonesia, the five leading organizations are the National Committee on Governance Policy (KNKG), the Forum for Corporate Governance in Indonesia (FCGI), the Association of Indonesian Issuers (AEI), the Indonesian Management Accountants Association (IAMI), and the Indonesian-Netherlands Association (INA) established a non-profit organization called the National Center for Sustainability Reporting (NCSR) in 2005. Through the establishment of the NCSR, it is hoped that companies can show accountability and transparency in carrying out social and environmental responsibilities. through published sustainability reports based on the reporting guidelines issued by GRI. A different phenomenon occurs in several other countries such as China, Denmark, South Africa and Malaysia. In these countries, the local government has obliged every company, both state-owned companies and public companies, to make sustainability reports, including a company engaged in the construction sector (Deegan, 2013; Iqbal et al., 2019; Istianingsih et al., 2020; Kim \& Todorovic, 2013). Meanwhile in Indonesia, the regulation regarding the construction service business is in Law no. 2 of 2017 concerning Construction Services which regulates that what is included in the construction service business is construction work planning consulting services, construction work implementation services and construction work supervision consulting services (Matei \& Drumasu, 2015; Mironiuc et al., 2013). The government policy that makes infrastructure development a priority is an opportunity for the construction service business in terms of economic performance. Referring to Law No.40 of 2007 regarding Limited Liability Companies, construction services are not one of the industrial sectors that are required to report their social responsibility because they are not engaged in natural resources. However, because there has been a shift in the business paradigm towards sustainability, Indonesian construction companies today feel the need to publish sustainability reports (Cho \& Patten, 2013; Deegan, 2013; Mahoney et al., 2013).

The key to business continuity in a construction company does not depend solely on the achievement of profit or profit. In addition to seeking maximum profit, companies must also pay attention to and be involved in fulfilling the welfare of its stakeholders (people) and take an active role in preserving the earth's environment (planet). One example of implementing this concept is green building certification. The certificate is a form of recognition of concern for environmental sustainability (Based on PT Waskita Karya's 2017 sustainability report). Meanwhile, the implementation of the triple bottom line commitment to the people aspect is manifested in the welfare of external stakeholders, especially the community through the implementation of community development and empowerment programs (Z. Ahmad et al., 2018; Deegan, 2013; Di Salvo et al., 2017; $\mathrm{Ng}, 2018)$. The various indicators contained in the GRI G4 are one of the tools for assessing company activities in maintaining business practices that support sustainability. Each company certainly has its own character in complying with these sustainability indicators (Iqbal et al., 2019; Kim \& Todorovic, 2013). It is adherence to the fulfillment of these indicators that is then conveyed by the company in its sustainability report (Cruz et al., 2020; Figueroa et al., 2010). So far, sustainability reports, especially in the construction sector, have only been made with the motivation of just fulfilling obligations, so that the quality of information submitted is only modest in accordance with what is required in the applicable regulations (Kim \& Todorovic, 2013; Ng, 2018). Moreover, due to the voluntary nature of sustainability reports, the quality of financial reports is not a priority and concern of the company. To ensure the quality and sustainability commitment made by companies, especially in the construction sector, a more in-depth study is needed on how completely construction service companies report their sustainability indicators in their sustainability reports. As a comparison, this research will also do the same thing for construction service companies in other countries, so this research intends to conduct a comparative study of the quality of GRI G4-based sustainability report disclosure for domestic and foreign construction service companies (Cho \& Patten, 2013; Deegan, 2013; Maichum et al., 2016).

The contribution of the research is that by knowing the description of the differences in the quality of disclosure in the sustainability report, the stakeholders in particular can consider drafting a regulation that can encourage the improvement of the quality of financial report disclosure, for example by changing policies from voluntary to mandatory based on the findings of existing empirical studies. 


\section{Literature Review}

\subsection{Sustainability Report and Construction}

The development of publishing sustainability reports from time to time has increased since 2000, where GRI reported at that time, only 44 companies worldwide published sustainability reports, while in 2016, GRI had received 32,118 sustainability reports. The increasing trend should be a sign that the company is currently paying more attention to matters related to sustainability. However, there are still strong indications that compliance with the sustainability aspect is merely an act of the company in the context of fulfilling obligations and complying with regulations, or even just a desire to get certain awards (Erhemjamts \& Huang, 2019; Stanojević et al., 2010). Previous research findings even found the fact that according to investors' perceptions, sustainability reports only reflect the impression of the company's management strategy to bring out the positives of sustainability performance and obscure the negative things of the company. The above phenomenon at least illustrates that the interests of companies or institutions that publish sustainability reports are still very heterogeneous and interesting for further research (Cho \& Patten, 2013; Deegan, 2013). Sustainable construction is an approach that begins with the construction sector's awareness of the importance of implementing the concept of sustainable development in the construction sector in creating the infrastructure it carries out in accordance with the main areas of environmental responsibility, social awareness and economic benefits (Bößner et al., 2019; Deng et al., 2013; Mc Williams \& Siegel, 2018). The concept of development in sustainable construction must be based on an understanding of the main principles for all generations. This study specifically intends to observe how the phenomenon of construction companies reports on their sustainability aspects according to the GRI G4 indicator. This is especially interesting from the perspective of Indonesia where the construction services sector is not yet a field that requires mandatory issuance of sustainability reports. In fact, business projects in the construction industry are one of the largest and most important sectors in the national economy and have a direct impact on the environment and society (Cai et al., 2019; Stanojević et al., 2010). The practice that occurs in China has established a mandatory system for sustainability reports, encouraging contractors to meet all sustainability indicators as part of the special characteristics of Chinese construction since the construction process began (Istianingsih et al., 2020). In different regions, the construction sector in Lithuania has a share of 6-10\% of GDP in the period 2007-2013, and consumes 50\% of energy needs, but is faced with many challenges that make the performance of the construction industry in Lithuania has a very large gap with standards. the performance of the construction sector in the European Union. These challenges make the construction industry in Lithuania must take a new approach to conform to the sustainability standards set by the European Union. Of course, the new approach must be simpler and have a priority scale so that it can be immediately fulfilled, therefore an approach is made based on important indicators as shown in Table 1.

\section{Table 1}

Indicators of sustainability in the Lithuanian construction sector

\begin{tabular}{|c|c|c|c|}
\hline Code & Criteria & Indicator & Type \\
\hline$I_{1}$ & Water consumption & $\mathrm{M}^{3} /$ net income & $\min$ \\
\hline$I_{2}$ & GHG Emission & $\mathrm{CO}_{2} \mathrm{t} / \mathrm{Net}$ income & $\min$ \\
\hline$I_{3}$ & Use of durable materials & Costs for durable materials/costs for all materials & $\max$ \\
\hline$I_{4}$ & Use of materials with low health risk & Costs for materials with low health risk/costs for all materials & $\max$ \\
\hline$I_{5}$ & Use of renewable energy & Renewable energy/all energy & $\max$ \\
\hline$I_{6}$ & Energy consumption & GJ/Net income & $\min$ \\
\hline$I_{7}$ & Project declared of general interest & Project costs / all costs & $\max$ \\
\hline$I_{8}$ & Safety and health of workers & Number of injuries/Total Number of employees & $\min$ \\
\hline$I_{9}$ & Leadership/knowledge management & Number of accredited professionals/Total Number of & $\max$ \\
\hline$I_{10}$ & Local workers during construction, operation and maintenance & Number of injuries/Total Number of employees & $\max$ \\
\hline$I_{11}$ & Training of workers & Yearly training hours/total number of employee & $\max$ \\
\hline$I_{12}$ & Reduction of direct costs & Direct costs/all costs & $\min$ \\
\hline$I_{13}$ & Reduction of indirect costs & Indirect costs/all costs & $\min$ \\
\hline$I_{14}$ & Maintenance costs & Maintenance costs/all costs & $\min$ \\
\hline$I_{15}$ & Construction time & Number of months/Net income & $\min$ \\
\hline
\end{tabular}

With this approach, according to the results of a study conducted in Lithuania, at least it shows what components need to be considered in compiling a sustainable construction project management portfolio. In the Indonesian context, from the results of this study, there is a tendency that construction companies that have low sustainability disclosure quality in the economic category are also followed by low achievement of indicators in the environmental and social categories (Ahmad et al., 2020; Atmadja et al., 2021). This is consistent with research on non-financial performance in other sectors, where good economic performance will usually be followed by good environmental and social performance (Isaac et al., 2019; Murphy, 1985). The study discusses the issue of sustainability has gone through a long and winding road. Although in terms of quantity it shows an increasing trend, there are still many notes for all parties who are concerned about this issue and leave work to immediately determine the value so that sustainability performance can be realized immediately (Thornton, 2013). Sustainability performance requires the focus of the company, the company's supply chain, and the sustainability context of the company itself so that it can be measured. Economic indicators are a determining factor in improving environmental performance in increasing the disclosure of sustainability reports in Indonesia and the world, while social factors play an important role in disclosing sustainability reports (Mahoney et al., 2013). 
In the Indonesian context, the issue of sustainability is not yet at measuring sustainability performance, but is still limited to fulfilling the obligations stipulated in the Law (Iqbal et al., 2019). This raises a condition in which the sector, which is still voluntary in reporting its sustainability condition, still has very few initiatives in preparing and publishing sustainability reports. In particular, the observations in this study were in the construction service sector in 2017, and only managed to find 8 construction companies that published sustainability reports (Kim \& Todorovic, 2013). Previous research in the construction sector in China has successfully identified factors that affect the willingness of construction service company owners to adopt sustainable construction, namely economic feasibility, awareness, support from project stakeholders, laws and regulations, operational feasibility of sustainable construction, sources of risk and project management models. Of the seven factors, the three most important according to the owner of a construction service company are economic feasibility, awareness and legislation (Law et al., 2016; $\mathrm{Ng}, 2018$; Tiwari \& Joshi, 2014). This is in line with findings in previous research that regulatory and awareness issues are important in driving sustainability performance (Cho \& Patten, 2013). In an effort to encourage the implementation of sustainable construction, the awareness of various parties is very much needed (Stanojević et al., 2010). In this case, the company as an important actor must have an awareness driven by an equal motivation. The achievement of its sustainability performance must be positioned as a medium to boost its economic performance, so that the trade-offs that occur are balanced. Sustainability reports can be quite effective media to convey performance achievements, as well as build a reputation for responsible behavior from the company along with achieving competitive advantage. The statement contains an emphasis that ensuring compliance is important (Di Salvo et al., 2017). Therefore, the existence of standards, although still global in nature, is relevant to be used as a reference in assessing the compliance of companies, especially construction services in the context of assessing sustainability performance (Istianingsih et al., 2020). This study chooses GRI G4 as the assessment standard to determine the quality of disclosure of sustainability reports in the construction service sector both at home and abroad. It is hoped that this research will present empirical facts about the quality of disclosure assessed based on all indicators in the GRI G4, between domestic (Indonesian) and foreign companies, as well as a basis for assessing the sustainability performance of each company.

\section{Methodology}

Research with a quantitative approach. The population in this study were construction companies in Indonesia and internationally. While the sample was taken by purposive sampling method with the sampling criteria being construction companies both in Indonesia and abroad that published sustainability reports in 2017. The type of data used in this study is secondary data in the form of sustainability reports during the 2017 period. This research was conducted to see the level of difference in sustainability report disclosure between construction companies in Indonesia and abroad. Descriptive statistical analysis is used to determine the characteristics of the sample used and to describe the variables in this study. Descriptive statistical analysis includes number of samples, minimum value, maximum value and average value (mean). The study used the Shapiro-wik test, used the Mann Whitney U Test (2 samples) for hypotheses 1,2 and 3, and the Kruskal Wallis test.

\section{Results and Discussion}

Based on the data obtained, the characteristics of the companies sampled in this study are presented in Table 2.

Table 2

List of Sample Companies based on Regional Characteristics

\begin{tabular}{|c|c|c|c|}
\hline No. & Company Territory & Company & Country \\
\hline 1 & Indonesia & Waskita Karya (Persero) Tbk & Indonesia \\
\hline 2 & & PP (Persero) Tbk & Indonesia \\
\hline 3 & & ABB Group & Indonesia \\
\hline 4 & & Bakrie \& Brothers Tbk & Indonesia \\
\hline 5 & & Total Bangun Persada & Indonesia \\
\hline 6 & & Wijaya Karya Beton & Indonesia \\
\hline 7 & & Wijaya Karya (Persero) Tbk & Indonesia \\
\hline 8 & & Posco E\&C & Indonesia \\
\hline 9 & & Hyundai E\&C & Seoul, South Korea \\
\hline 10 & & Consolidated Contractors Company (CCC) & Athens, Greece \\
\hline 11 & & Chiyoda Group & Japan \\
\hline 12 & & Mytilineos & Greece \\
\hline 13 & & CTCI & Taiwan \\
\hline 14 & & Lotte E\&C & Korea Selatan \\
\hline 15 & & Enka & Turkey \\
\hline 16 & & $\mathrm{CRH}$ & Dublin, Republik Irlandia \\
\hline 17 & & PEAB AB & Swedia \\
\hline 18 & & Daewoo E\&C & Seoul, Korea Selatan \\
\hline 19 & & NWS Holding Limited & Hong Kong \\
\hline 20 & Other countries & HOCHTIEF & Nordrhein-Westfalen, Jerman \\
\hline
\end{tabular}


Table 2

List of Sample Companies based on Regional Characteristics (Continued)

\begin{tabular}{|c|c|c|c|}
\hline No. & Company Territory & Company & Country \\
\hline 21 & & China Resources Land Ltd & Hong Kong \\
\hline 22 & & AECOM & California, Amerika \\
\hline 23 & & Fletcher Building & Auckland, New Zealand \\
\hline 24 & & Maire Technimont & Rome, Italy \\
\hline 25 & & The Bechtel & Reston, Virginia, Amerika \\
\hline 26 & & BAM & Bunnik, Belanda \\
\hline 27 & & Volker Wessels & Belanda \\
\hline 28 & & Motaengil & Norte Region, Portugal \\
\hline 29 & & Taylor Wimpey & Britania Raya, England \\
\hline 30 & & Larsen \& Toubro & Mumbai, India \\
\hline
\end{tabular}

Based on the findings regarding the quality of the sustainability report disclosure, Table 3 shows descriptive statistics that show the quality of disclosure of the three indicators.

Table 3

Descriptive Statistics Table of Quality of Sustainability Report Disclosure for the Three Indicators

\begin{tabular}{lccccccc}
\hline & $\mathbf{N}$ & Minimum & Maximum & Mean & Std. Error & Std. Deviation & Average score of the Indicator \\
\hline Economic & 30 & 46 & 104 & 85.93 & 2.848 & 15.600 & 31.898 \\
Environmental & 30 & 208 & 395 & 314.73 & 9.475 & 3,05 \\
Social & 30 & 226 & 426 & 356.20 & 8.423 & 46.137 \\
\hline
\end{tabular}

Based on Table 3, it can be concluded that the economic indicators have 26 sub-chapters, then the mean or average value is $85.93 / 26=3.305$, which means that the average contribution of economic variables in the disclosure of sustainability reports for construction companies in Indonesia and the world is disclosed according to GRI. G4 at a minimum. Environmental indicators have 102 sub-chapters, so the mean or average value is $314.73 / 102=3.085$, which means that the average contribution of environmental variables in the disclosure of sustainability reports for construction companies in Indonesia and the world is minimally disclosed according to GRI G4. While the social indicators have 109 sub-chapters, the mean or average value is $356.20 / 109=3.267$, which means that the average contribution of social variables in disclosing sustainability reports to construction companies in Indonesia and the world is minimally disclosed according to GRI G4. If you look at the findings in the descriptive statistics above, all indicators have an average score of relatively the same quality of disclosure, namely minimally disclosing compliance according to the GRI G4 indicator. From these results, it is likely that the hypothesis test results will also lead to the same thing, namely that there is no difference. The best average value, which is 3.085, means the most transparent in disclosing sustainability reports (Bach et al., 2020; Dhawan et al., 2019). This shows that the economic indicators of construction companies in Indonesia and the world in 2017 are more transparent than the environmental and social indicators in presenting the disclosure of the GRI G4-based sustainability report.

\subsection{Feasibility / Normality Test Results}

The second test that is done is the data normality test. The results of the findings of this study on the data normality test are presented in Table 4.

Table 4

Normality Test for the Three Indicators

\begin{tabular}{|c|c|c|c|c|c|c|c|}
\hline & \multirow[t]{2}{*}{ Company Territory } & \multicolumn{3}{|c|}{ Kolmogorov-Smirnova } & \multicolumn{3}{|c|}{ Shapiro-Wilk } \\
\hline & & Statistic & df & Sig. & Statistic & df & Sig. \\
\hline \multirow[t]{2}{*}{ Economic } & Indonesia & 0.124 & 8 & $0.200^{*}$ & 0.949 & 8 & 0.705 \\
\hline & Dunia & 0.134 & 22 & $0.200^{*}$ & 0.911 & 22 & 0.050 \\
\hline \multirow[t]{2}{*}{ Environmental } & Indonesia & 0.192 & 8 & $0.200^{*}$ & 0.898 & 8 & 0.275 \\
\hline & Dunia & 0.108 & 22 & $0.200^{*}$ & 0.970 & 22 & 0.701 \\
\hline \multirow[t]{2}{*}{ Social } & Indonesia & 0.225 & 8 & $0.200^{*}$ & 0.924 & 8 & 0.460 \\
\hline & Dunia & 0.145 & 22 & $0.200^{*}$ & 0.926 & 22 & 0.102 \\
\hline
\end{tabular}

Based on Table 4, in the economic indicators, all significant values based on the Shapiro-Wilk test $>0.05$, so the two groups are equally distributed normally. This also occurs in environmental and social indicators, so it can be said that the data for the three indicators are normally distributed.

\subsection{Hypothesis test Mann Whitney U-Test}

Mann-Whitney U Test for all indicators of Construction Companies in Indonesia and the World in 2017

To prove the alleged research results in accordance with the trend of the descriptive statistical test results, the Mann-Whitney $\mathrm{U}$ Test was carried out with the results as shown in Table 5. 
Table 5

Mann-Whitney U Test for the Three Ranks Indicators

\begin{tabular}{llrlll}
\hline & Company Territory & $\mathrm{N}$ & Mean Rank & Sum of Ranks \\
\hline \multirow{2}{*}{ Economic } & Indonesia & 8 & 17.56 & 140.50 \\
& Dunia & 22 & 14.75 & 324.50 \\
\hline Environmental & Indonesia & 8 & 19.31 & 154.50 \\
& Dunia & 22 & 14.11 & 310.50 \\
\hline Social & Indonesia & 8 & 16.62 & 133.00 \\
& Dunia & 22 & 15.09 & 332.00 \\
\hline
\end{tabular}

Table 6

$\underline{\text { Statistical Test Results }}$

\begin{tabular}{llll}
\hline & Economic & Environmental & Social \\
\hline Mann-Whitney U & 71.500 & 57.500 & 79.000 \\
Wilcoxon W & 324.500 & 310.500 & 332.000 \\
Z & -.775 & -1.431 & -.422 \\
Asymp. Sig. (2-tailed) & .439 & .153 & .673 \\
\hline
\end{tabular}

From Table 5, the average ranking of disclosure of economic indicators in Indonesian construction companies is 17.56 and in the world is 14.75. This shows that the disclosure of economic indicators in construction companies in the world is more open than that of construction companies in Indonesia. The $\mathrm{U}$ value is 71.5 and the $\mathrm{W}$ value is 324.5 . If converted to $\mathrm{Z}$ value, the magnitude is -0.775 . The significance value of the p-value is 0.439 ; then $\mathrm{H} 0$ is accepted. This means that there is no difference in the disclosure of economic indicators in domestic and foreign construction companies. The second finding is that the average ranking of environmental indicator disclosure in Indonesian construction companies is 19.31 and in the world it is 14.11. This shows that the disclosure of environmental indicators in construction companies in the world is more open than that of construction companies in Indonesia. The $\mathrm{U}$ value is 57.5 and the $\mathrm{W}$ value is 310.5 . If converted to $\mathrm{Z}$ value, the magnitude is $-1,431$. The significance value of the p-value is 0.153 ; then $\mathrm{H} 0$ is accepted. This means that there is no difference in the disclosure of environmental indicators in domestic and foreign construction companies. The third finding is the average rating for disclosure of environmental indicators in Indonesian construction companies of 19.31 and 14.11 in the world. This shows that the disclosure of environmental indicators in construction companies in the world is more open than that of construction companies in Indonesia. The $\mathrm{U}$ value is 57.5 and the $\mathrm{W}$ value is 310.5 . If converted to $Z$ value, the magnitude is $-1,431$. The significance value of the p-value is 0.153 ; then $\mathrm{H} 0$ is accepted. This means that there is no difference in the disclosure of environmental indicators in domestic and foreign construction companies. The results of the mean rank or the average ranking of each group on the three indicators together in Indonesian construction companies the average rank is 17.75 and world companies are 14.68. This shows that the disclosure of the three indicators together in construction companies in the world is more open than that of construction companies in Indonesia.

The results of this study are in line with research with the title Integrating Sustainability in Business Model Disclosure: Evidence from the UK Mining Industry. The results of these studies indicate that mining companies have chosen a selective and malleable approach to sustainability (Iqbal et al., 2019; Thornton, 2013). While water, energy, local community engagement, environmental protection and labor conditions are frequently discussed in the business model of British mining companies, there is very little evidence to suggest that initiatives are being implemented in other areas. In fact, some topics are either completely ignored (raw materials), almost completely ignored (waste, corruption and lobbying, local jobs), or discussed descriptively (human rights, opportunity and equity, recruitment and bargaining, training). The sustainability strategy in the mining industry affects only part of the components of the business model, and that the impact varies consistently between sustainability topics (Cho \& Patten, 2013; Cruz et al., 2020; Deegan, 2013; Istianingsih et al., 2020). This proves that the disclosure of the sustainability report in the mining business sector is not yet transparent (Cho \& Patten, 2013; Iqbal et al., 2019; Kim \& Todorovic, 2013; Thornton, 2013).

\section{Conclusion}

The results of the research above can be concluded that the analysis with the Mann-Whitney U Test on each indicator and the Kruskal-Wallis test on the three variables together shows that in quality there is no difference in sustainability report disclosure in construction companies in Indonesia and the world. which is based on GRI G4. Comparison of the sample size of Indonesian companies with the world, namely 8:22, shows that the disclosure of sustainability reports in Indonesian construction companies can only be done by large and bona fide companies. However, from the comparison of the quality of the disclosure with similar companies abroad, the results are the same, namely there is no difference in the quality of the sustainability report disclosure on all indicators based on GRI G4. There are several limitations in this study, namely; There is only one variable used in this study, namely the sustainability report which is used as a basis for conducting different tests, this study only examines in one period of time so that the conclusions found cannot be compared with the previous year, and this study only uses descriptive research methods with quantitative approach and use secondary data only without conducting interviews so that conclusions are only based on written documents. This study contributes to information that the quality of sustainability report disclosure in several countries still relies on the element of compliance with regulations alone but has not yet been fully adopted by companies in their daily business practices. In the future, a more integrated 
approach is needed so that sustainability reports become a media that has more power to determine the strategic direction of the company.

\section{References}

Ahmad, W. W., Manurung, D. T. H., Saputra, K. A. K., \& Mustafa, S. G. (2020). Corporate Social Responsibility And Firm Financial Performance: A Case Of Sme's Sector In Pakistan. Journal of Chemical Information and Modeling, 1(2), 6274.

Ahmad, Z., Ibrahim, H., \& Tuyon, J. (2018). Governance of behavioural biases in asset management industry: Insights from fund managers in Malaysia. Asian Academy of Management Journal of Accounting and Finance, 14(2), 65-102. https://doi.org/10.21315/aamjaf2018.14.2.4

Atmadja, A. T., \& Saputra, K. A. K. (2018). Determinant Factors Influencing The Accountability Of Village Financial Management. Academy of Strategic Management Journal, 17(1), 1-9.

Atmadja, A. T., Saputra, K. A. K., Tama, G. M., \& Paranoan, S. (2021). Influence of Human Resources. Journal of Asian Finance, Economics and Business, 8(2), 563-570. https://doi.org/10.13106/jafeb.2021.vol8.no2.0563

Bach, M. P., Starešinić, B., Omazić, M. A., Aleksić, A., \& Seljan, S. (2020). m-Banking quality and bank reputation. Sustainability (Switzerland), 12(10), 1-18. https://doi.org/10.3390/su12104315

Bößner, S., Devisscher, T., Suljada, T., Ismail, C. J., Sari, A., \& Mondamina, N. W. (2019). Barriers and opportunities to bioenergy transitions: An integrated, multi-level perspective analysis of biogas uptake in Bali. Biomass and Bioenergy, 122(January 2018), 457-465. https://doi.org/10.1016/j.biombioe.2019.01.002

Buslepp, W., Legoria, J., Rosa, R., \& Shaw, D. (2019). Advances in Accounting Misclassi fi cation of audit-related fees as a measure of internal control quality. Advances in Accounting, 46, 100425. https://doi.org/10.1016/j.adiac.2019.100425

Cai, C., Zheng, Q., \& Zhu, L. (2019). The effect of shared auditors in the supply chain on cost stickiness. China Journal of Accounting Research, 12(4), 337-355. https://doi.org/10.1016/j.cjar.2019.09.001

Cho, C. H., \& Patten, D. M. (2013). Green accounting: Reflections from a CSR and environmental disclosure perspective. Critical Perspectives on Accounting, 24(6), 443-447. https://doi.org/10.1016/j.cpa.2013.04.003

Cruz, P. D. La, Acosta, L. E., Mendoza, D., Baltazar, E. B., Arce Ibarra, A. M., \& Lugo, E. I. . E. (2020). Indicators of wellbeing among indigenous peoples of the Colombian Amazon: Tensions between participation in public policy making and autonomy. Environmental and Sustainability Indicators, 7(March), 100044. https://doi.org/10.1016/j.indic.2020.100044

Deegan, C. (2013). The accountant will have a central role in saving the planet . really? A reflection on "green accounting and green eyeshades twenty years later." Critical Perspectives on Accounting, 24(6), 448-458. https://doi.org/10.1016/j.cpa.2013.04.004

Deng, X., Kang, J. koo, \& Low, B. S. (2013). Corporate social responsibility and stakeholder value maximization: Evidence from mergers. Journal of Financial Economics, 110(1), 87-109. https://doi.org/10.1016/j.jfineco.2013.04.014

Dhawan, R., Bisht, B. M. S., Kumar, R., Kumari, S., \& Dhawan, S. K. (2019). Recycling of plastic waste into tiles with reduced flammability and improved tensile strength. Process Safety and Environmental Protection, 124, $299-307$. https://doi.org/10.1016/j.psep.2019.02.018

Di Salvo, A. L. A., Agostinho, F., Almeida, C. M. V. B., \& Giannetti, B. F. (2017). Can cloud computing be labeled as "green"? Insights under an environmental accounting perspective. Renewable and Sustainable Energy Reviews, 69(November 2016), 514-526. https://doi.org/10.1016/j.rser.2016.11.153

Erhemjamts, O., \& Huang, K. (2019). Institutional ownership horizon, corporate social responsibility and shareholder value. Journal of Business Research, 105(January 2018), 61-79. https://doi.org/10.1016/j.jbusres.2019.05.037

Figueroa, B., E., Orihuela, R., C., \& Calfucura, T., E. (2010). Green accounting and sustainability of the Peruvian metal mining sector. Resources Policy, 35(3), 156-167. https://doi.org/10.1016/j.resourpol.2010.02.001

Iqbal, S., Nawaz, A., \& Ehsan, S. (2019). Financial performance and corporate governance in microfinance: Evidence from Asia. Journal of Asian Economics, 60. https://doi.org/10.1016/j.asieco.2018.10.002

Isaac, O., Abdullah, Z., Aldholay, A. H., \& Abdulbaqi Ameen, A. (2019). Antecedents and outcomes of internet usage within organisations in Yemen: An extension of the Unified Theory of Acceptance and Use of Technology (UTAUT) model. Asia Pacific Management Review, 24(4), 335-354. https://doi.org/10.1016/j.apmrv.2018.12.003

Istianingsih, Trireksani, T., \& Manurung, D. T. H. (2020). The impact of corporate social responsibility disclosure on the future earnings response coefficient (Asean banking analysis). Sustainability (Switzerland), 12(22), 1-16. https://doi.org/10.3390/su12229671

Karmawan. (2017). Role and Contribution of Village Financial Management to Realize Transparency And Accountable Village Budgeting Revenue And Expenditure District of West Bangka. Advances in Economics, Business and Management Research, 46(1), 293-299.

Kim, J. T., \& Todorovic, M. S. (2013). Towards sustainability index for healthy buildings - Via intrinsic thermodynamics, green accounting and harmony. Energy and Buildings, 62, 627-637. https://doi.org/10.1016/j.enbuild.2013.03.009

Law, A., De Lacy, T., Lipman, G., \& Jiang, M. (2016). Transitioning to a green economy: The case of tourism in Bali, Indonesia. Journal of Cleaner Production, 111, 295-305. https://doi.org/10.1016/j.jclepro.2014.12.070

Lombardi, R., Trequattrini, R., Cuozzo, B., \& Cano-rubio, M. (2019). Corporate corruption prevention , sustainable governance and legislation: First exploratory evidence from the Italian scenario. Journal of Cleaner Production, 217, 666-675. https://doi.org/10.1016/j.jclepro.2019.01.214 
Mahoney, L. S., Thorne, L., Cecil, L., \& LaGore, W. (2013). A research note on standalone corporate social responsibility reports: Signaling or greenwashing? Critical Perspectives on Accounting, 24(4-5), 350-359. https://doi.org/10.1016/j.cpa.2012.09.008

Maichum, K., Parichatnon, S., \& Peng, K. C. (2016). Application of the extended theory of planned behavior model to investigate purchase intention of green products among Thai consumers. Sustainability (Switzerland), 8(10). https://doi.org/10.3390/su8101077

Malizia, A., \& Monmany-Garzia, A. C. (2019). Terrestrial ecologists should stop ignoring plastic pollution in the Anthropocene time. Science of the Total Environment, 668, 1025-1029. https://doi.org/10.1016/j.scitotenv.2019.03.044

Matei, A., \& Drumasu, C. (2015). Corporate Governance and Public Sector Entities. Procedia Economics and Finance, 26(December), 495-504. https://doi.org/10.1016/s2212-5671(15)00879-5

Mc Williams, A., \& Siegel, D. (2018). Corporate social responsibility: A theory of the firm perspective. Business Ethics and Strategy, Volumes I and II, 26(1), 137-147. https://doi.org/10.4324/9781315261102-8

Mdee, A., \& Thorley, L. (2016). Good governance, local government, accountability and service delivery in Tanzania. Economic and Social Research Council.

Mironiuc, M., Chersan, I.-C., \& Robu, I.-B. (2013). Ethics in Providing Non-Audit Services to Ensure Transparency in Financial Reporting. Procedia - Social and Behavioral Sciences, 81, $474-478$. https://doi.org/10.1016/j.sbspro.2013.06.463

Murphy, K. J. (1985). Corporate performance and managerial remuneration. An empirical analysis. Journal of Accounting and Economics, 7(1-3), 11-42. https://doi.org/10.1016/0165-4101(85)90026-6

Nagy, S. G., Kováts, G., \& Németh, A. O. (2014). Governance and Funding of Higher Education - International Trends and Best Practices. Procedia - Social and Behavioral Sciences, 116, $180-184$. https://doi.org/10.1016/j.sbspro.2014.01.190

$\mathrm{Ng}$, A. W. (2018). From sustainability accounting to a green financing system: Institutional legitimacy and market heterogeneity in a global financial centre. Journal of Cleaner Production, 195, 585-592. https://doi.org/10.1016/j.jclepro.2018.05.250

Saputra, K. A. K., Jayawarsa, A. A. K., \& Atmadja, A. T. (2019). Resurrection as a fading implication of accountability in financial management for village credit institution. International Journal of Business, Economics and Law, 19(5), 258268.

Stanojević, M., Vranes, S., \& Gökalp, I. (2010). Green accounting for greener energy. Renewable and Sustainable Energy Reviews, 14(9), 2473. https://doi.org/10.1016/j.rser.2010.06.020

Thornton, D. B. (2013). Green accounting and green eyeshades twenty years later rejoinder to critics. Critical Perspectives on Accounting, 24(6), 474-476. https://doi.org/10.1016/j.cpa.2013.05.003

Tiwari, P. C., \& Joshi, B. (2014). ScienceDirect Local and regional institutions and environmental governance in Hindu Kush Himalaya. Environmental Science and Policy, 49, 66-74. https://doi.org/10.1016/j.envsci.2014.09.008

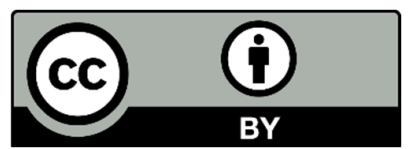

(C) 2022 by the authors; licensee Growing Science, Canada. This is an open access article distributed under the terms and conditions of the Creative Commons Attribution (CC-BY) license (http://creativecommons.org/licenses/by/4.0/). 